\title{
CHEMICAL AND BIOLOGICAL ANALYSES OF MALAYSIAN STINGLESS BEE PROPOLIS EXTRACTS
}

\author{
(Analysis Kimia dan Biologi Ekstrak Propolis Lebah Kelulut Malaysia) \\ Nurhamizah Ibrahim ${ }^{1}$, Nurul Farah Shakila Mohd Niza ${ }^{1}$, Muhammad Muslim Mohd Rodi $^{2}$, \\ Abdul Jamil Zakaria ${ }^{2}$, Zhari Ismail ${ }^{3}$, Khamsah Suryati Mohd ${ }^{1,2}$ \\ ${ }^{1}$ School of Agriculture and Biotechnology, Faculty of Bioresources and Food Industry \\ ${ }^{2}$ Agriculture Production and Food Innovation Research Institute (AGROPOLIS UniSZA) \\ Universiti Sultan Zainal Abidin, Tembila Campus, 22200 Besut, Terengganu, Malaysia \\ ${ }^{3}$ School of Pharmaceutical Sciences, \\ Universiti Sains Malaysia, 11800 Penang, Malaysia \\ *Corresponding author: caldinamiez@gmail.com
}

Received: 14 April 2015; Accepted: 30 November 2015

\begin{abstract}
The aim of this study is to evaluate chemical and biological profile of methanol extracts from Malaysian propolis produced by two commonly found stingless bee species, Heterotrigona itama (MHI) and Geniotrigona thoracica (MGT). Test samples were analyzed for physicochemical parameters such as moisture, fat, crude fibre, crude protein, carbohydrate and ash content. Tests for phytochemical screening by thin layer chromatography of both extracts revealed that presence of terpenoids, flavonoids, phenols and essential oils but steroids, saponin and coumarins only occur in MHI. Both extracts displayed a characteristic profile and vary from each other. Accordingly, MHI possess higher antioxidant activity with an $\mathrm{IC}_{50}$ of $15.0 \pm 0.21 \mathrm{ug} / \mathrm{mL} \mathrm{compared} \mathrm{to}$ MGT with $\mathrm{IC}_{50}$ of $270.0 \pm 0.19 \mathrm{ug} / \mathrm{mL}$. MHI showed moderate nitric oxide scavenging activity, while MGT only showed mild inhibition. Antidiabetic activity was determined by $\alpha$-glucosidase inhibition and found significantly better than that of acarbose (positive control). In conclusion, data gathered in this study revealed that bee species play role in determining the chemical and biological profile of particular propolis and should put into account in decision of further development for propolis.
\end{abstract}

Keywords: physico-chemical, phytochemical, TLC profiling, antioxidant, antidiabetic

\section{Abstrak}

Tujuan kajian ini adalah untuk menilai profil kimia dan biologi ekstrak metanol propolis dari Malaysia yang dihasilkan oleh dua species lebah kelulut yang biasa dijumpai, Heterotrigona itama (MHI) dan Geniotrigona thoracica (MGT). Sampel telah dianalisis untuk parameter fizikokimia seperti kelembapan, lemak, serat kasar, protein mentah, karbohidrat dan kandungan abu. Pemeriksaan keatas analisis fitokimia menggunakan kromatografi lapisan nipis untuk kedua-dua ekstrak menunjukkan kehadiran terpenoid, flavonoid dan minyak pati tetapi steroid, saponin dan coumarin hanya wujud dalam MHI. Kedua - dua ekstrak menunjukkan profil yang berbeza antara satu sama lain. Sehubungan itu juga, MHI mempunyai aktiviti antioksidan yang lebih tinggi dengan $\mathrm{IC}_{50} 15.0 \pm 0.21 \mathrm{ug} / \mathrm{mL}$ berbanding MGT $(270.0 \pm 0.19 \mathrm{ug} / \mathrm{mL})$. MHI menunjukkan aktiviti perencatan nitrik oksida yang sederhana, sementara MGT menunjukkan perencatan yang sedikit sahaja. Aktiviti antidiabetik telah ditentukan menggunakan perencatan $\alpha$-glukosida dan didapati lebih baik secara signifikan daripada acarbose (kawalan positif). Kesimpulannya, data yang dikutip dalam kajian ini menunjukkan bahawa spesies lebah memainkan peranan dalam menentukan profil kimia dan biologi propolis tertentu dan perlu dipertimbangkan dalam membuat keputusan untuk pembangunan propolis.

Kata Kunci: fisikokimia, fitokimia, profil KLN, antioksidan, antidiabetik 


\section{Introduction}

Propolis is a complex resinous substance manufactured by stingless bees and these resins are used to line the inside of nest cavities and reduce the size of hive entrances. The composition of propolis depends on the type of plants accessible to the bees. Propolis has a wide range of biological activities, as antibacterial [1], anti-inflammatory [2], antiulcer [3], antioxidant [4], hepatoprotective [5], and tumoricidal [6] activities and high repellent index against ants [7]. It is generally accepted that bees collect resinous plant materials, produced by a variety of botanical processes, in different parts of plants.

The specificity of local flora is responsible for the chemical composition of propolis [8]. The chemical compositions and biological activities of propolis are attributed to plant sources, geographical area and collecting season $[9,10]$. Since bees use the natural available vegetation to create propolis, there is a high variability in the composition of propolis [11]. Propolis has over 150 constituents and its rich in biochemical constituents, including mostly a mixture of polyphenols, flavonoid aglycones, phenolic and ketones [12]. The most studied component was flavonoids and phenolic compounds and they have been reported as the types of antioxidant that possess a strong inhibitory effect against lipid oxidation through radical-scavenging. Besides that, contents of flavonoid and other phenolic substances have been suggested to play a preventative role in the development of cancer and heart disease [13, 14].

In Malaysia, research in propolis has been carried out sparsely. Until now, there are only some preliminary investigations on the composition and biological activity of Malaysian propolis from stingless bee. The present study is an attempt to investigate the physicochemical, preliminary phytochemical, TLC profiling and biological activity of two methanol extracts of propolis that produced from MHI and MGT. Data generate from this study will be a basis of future work on development of Malaysian propolis for health-related products.

\section{Chemicals and reagents}

\section{Materials and Methods}

DPPH and Folin-Ciocalteu's reagent (Sigma-Aldrich). Sodium carbonate $\left(\mathrm{Na}_{2} \mathrm{CO}_{3}\right)$, aluminium chloride $\left(\mathrm{AlCI}_{3}\right)$, sodium nitrite $\left(\mathrm{NaNO}_{2}\right)$, and sodium hydroxide $(\mathrm{NaOH})$ were aquired from Merck, Germany. Methanol was used as a solvent for the preparation of samples, toluene, ethyl acetate and formic acid (8: 2: 0.1) used as mobile phase for TLC analysis. All chemicals used were of analytical grade.

\section{Collection and preparation of propolis}

Propolis used in this study was collected from AGROPOLIS Apiary, Agriculture Production and Food Innovation Research Institute (AGROPOLIS UniSZA), Universiti Sultan Zainal Abidin. Each sample was cleaned and froze in $-20^{\circ} \mathrm{C}$, then ground to powder. Propolis extract was prepared by infusing $7 \mathrm{~g}$ of crude propolis in $70 \mathrm{~mL}$ of $80 \% \mathrm{v} / \mathrm{v}$ methanol solution for at least 3 days. The extracts were filtered and dried under pressure using rotary evaporator. Crude propolis and extracts were kept cool $\left(-20^{\circ} \mathrm{C}\right)$ prior analysis. Propolis produced by H. itama coded as MHI and propolis produced by G. thoracica coded as MGT.

\section{Physicochemical analysis}

MHI and MGT of propolis were subjected for determination of physicochemical parameters such as moisture, fat, crude fibre, crude protein, carbohydrate and ash content were carried out according to the methods described in pharmacopoeia $[17,18]$

\section{Phytochemical screening by Thin Layer Chromatography}

MHI and MGT of propolis extracts were screened for the presence of various classes of compounds according to the standard screening method [19] using thin-layer chromatography (TLC) with silica gel G (Merck $60 \mathrm{~F}_{254}$ ) plates of $0.05 \mathrm{~mm}$ thickness. The extracts were dissolved in methanol, while the development of the plate was carried out using mobile systems toluene: ethyl acetate: formic acid (8: 2: $0.1 \mathrm{v} / \mathrm{v})$ for MHI and MGT extracts. After development, the plates were sprayed by various chemical reagents such as anisaldehyde, vanillin-sulphuric acid and iodine for detection of the respective classes of compounds.

\section{DPPH free radical-scavenging activity}

The ability of MHI and MGT to scavenge 2,2-diphenyl-1-picrylhydrazyl (DPPH) was determined by DPPH free 
radical scavenging activity assay. The scavenging effect of extracts for DPPH was performed based on the method described [20] with a slight modification. Quercetin was used as positive control. One mili Molar of DPPH solution was prepared by diluting $3.94 \mathrm{mg}$ DPPH in $10 \mathrm{~mL}$ methanol. $200 \mu \mathrm{L}$ of standard and sample solution (800, 400, $200,100,50,25,12.5$ and $6.25 \mu \mathrm{g} / \mathrm{mL}$ ) were added into a 96 well micro plate. Then, $50 \mu \mathrm{L}$ of $1 \mathrm{mM}$ DPPH solution was mixed into each well and were left at room temperature in the dark place for 30 minutes. After 30 minutes of incubation period, the absorbance was read at $517 \mathrm{~nm}$ by Elisa reader spectrophotometer. The blank sample is 200 $\mu \mathrm{L}$ methanol and $50 \mu \mathrm{L}$ of $1 \mathrm{mM}$ DPPH. All sample extracts were made in triplicate. The ability of different propolis extracts and positive controls to scavenge the DPPH free radical was calculated using the formula, as shown in equation below:

$$
\text { Inhibition \% }=\left[\left(\mathrm{A}_{\text {Blank }}-\mathrm{A}_{\text {Sample }}\right) / \mathrm{A}_{\text {Blank }}\right] \times 100 \%
$$

$\mathrm{A}_{\mathrm{Blank}}$ is the absorbance of $1 \mathrm{mM}$ of DPPH solution with methanol while $\mathrm{A}_{\text {Sample }}$ is the absorbance of the propolis sample extracts and positive control solution. The lower absorbance indicates a higher scavenging activity followed by decreasing the intensity of purple to yellow colour. The radical scavenging activities of crude extracts were interpreted via $\mathrm{IC}_{50}$ values. The $\mathrm{IC}_{50}$ is a concentration that can scavenge the $50 \%$ of DPPH free radical.

\section{Nitric Oxide assay}

The nitric oxide (NO) scavenging activity of the extract was measured according to the method described by Ho et al. [21]. $50 \mu \mathrm{L}$ of propolis extracts were added into $50 \mu \mathrm{L}$ of $10 \mathrm{M}$ sodium nitroprusside solution in 96 -well flatbottomed plate and then incubated under light at room temperature for $90 \mathrm{~min}$. Finally, an equal volume of Griess reagent ( $1 \%$ of sulphanilamide and $0.1 \%$ of naphthylethylenediamine in $2.5 \% \mathrm{HPO}_{3}$ ) was added to each well to measure the nitrite content immediately at $546 \mathrm{~nm}$. L-ascorbic acid was evaluated as a reference standard. All experiments were carried out in triplicate. The percentage scavenging activity was calculated as described for DPPH assay.

\section{Antidiabetic activity}

The enzyme inhibition activity for $\alpha$-glucosidase was assessed according to the method described by Sancheti et al. [22] with minor modifications to determine the potential of MHI and MGT propolis extract for antidiabetic activity. The reaction mixture contained $50 \mu \mathrm{L}$ of $0.1 \mathrm{M}$ phosphate buffer ( $\mathrm{pH} 7.0), 25 \mu \mathrm{L}$ of $0.5 \mathrm{mM} 4$-nitrophenyl $\alpha$-Dglucopyranoside, $10 \mu \mathrm{L}$ of extract sample at various concentrations and $25 \mu \mathrm{L}$ of $\alpha$-glucosidase solution $(0.2$ Unit $/ \mathrm{mL}$ ). This reaction mixture was then incubated at $37{ }^{\circ} \mathrm{C}$ for $30 \mathrm{~min}$. The reaction was terminated by adding 100 $\mu \mathrm{L}$ of $0.2 \mathrm{M}$ sodium carbonate solution. The enzymatic hydrolysis of substrate was monitored by the amount of $\mathrm{p}-$ nitrophenol released in the reaction mixture at $410 \mathrm{~nm}$ using microplate reader. Individual blanks were prepared for correcting the background absorbance, where the enzymes were replaced with buffer. Controls were conducted in an identical manner replacing the extracts with methanol. Acarbose was used as positive control. All experiments were carried out in triplicates. The inhibition percentage of $\alpha$-glucosidase was assessed by the following formula:

$$
\% \text { Inhibition }=[1-(\text { sample absorbance } / \text { control absorbance })] \times 100
$$

\section{Statistical analysis}

Triplicate determinations, mean and standard deviation were calculated. Calibration curve of standard was obtained for concentration versus absorbance. All data were subjected for analysis using independent variable t-test.

\section{Physicochemical evaluation}

\section{Results and Discussion}

Bees produce propolis as part of their defense system in order to protect their hive from invaders and microbial attacks. In this study, we collected propolis produced by two different species of stingless bees, H. itama and G. thoracica from our Apiary. Even though the location was the same and the distance between hives of these two species is only few meters apart, the physicochemical content such as moisture, fat, crude fibre, protein, soluble extractive and ash content were markedly different as shown in Table 1. MHI contains noticeable high moisture content compared to MGT, ranged from $9.90-23.72 \%$. The lower of moisture content of MGT could prevent bacterial, fungal or yeast growth through storage [23]. The ash values, total ash was found to be in the ranged from 
$4.11-5.99 \%$, where MGT contain higher value compared to MHI. Ash values used to determine quality and purity of crude samples. It indicates the presence of various impurities like carbonate, oxalate and silicate. MHI had lower percentage of crude fat content in comparison with MGT. However, in contrast, MGT have a lower carbohydrate content but slightly higher in fibre. Meanwhile, protein content of both samples was in close range, $2.17-3.87 \%$. The differences of MHI and MGT physicochemical content might due to vegetation preferences of the bee species [14].

Table 1. Physicochemical analysis of the methanol extracts propolis produced by stingless bees, H. itama (MHI) and G. thoracica (MGT) $(p<0.05)$

\begin{tabular}{lcc}
\hline Parameter & MHI & MGT \\
\hline Moisture (\%) & $23.72 \pm 0.62^{1}$ & $9.90 \pm 11.82$ \\
Ash (\%) & $4.11 \pm 0.67$ & $5.99 \pm 0.31$ \\
Crude fat (\%) & $21.43 \pm 5.39$ & $73.47 \pm 2.75$ \\
Crude protein (\%) & $3.80 \pm 0.12$ & $2.17 \pm 0.15$ \\
Crude fibre (\%) & $44.36 \pm 5.07$ & $67.48 \pm 1.50$ \\
Carbohydrates (\%) & $49.60 \pm 9.19$ & $8.46 \pm 10.32$ \\
\hline
\end{tabular}

${ }^{I}$ Each value is the average of three analyses \pm standard deviation

\section{Chemical fingerprint by Thin Layer Chromatography analysis}

Propolis is a complex resinous mixture, which contains approximately $50 \%$ resin that composed of flavonoids and related to phenolic acids regarded as the polyphenolic compounds, $30 \%$ wax, $10 \%$ essential oils, $5 \%$ pollen and 5 $\%$ various organic compounds [12]. The chemical composition of propolis reportedly depends on the specificity of the local flora at the site collection and also the vegetation preference of stingless bee species. As seen in Table 2, the chemical compositions of propolis were tested by TLC profiling of MHI and MGT in different chemical reagents for detection of the respective classes of compound. There were three reagent used during this step which were iodine, anisaldehyde and also vanillin. TLC plate was stained with iodine vapor to visualize organic compound since iodine has a high affinity for both unsaturated and aromatic compounds such as polycyclic aromatic compounds, phenolic steroid, ester and alkaloids. Anisaldehyde was used to detect aldehyde, phenol, sugar and terpenes compound. When heated, the TLC plate change to light pink color and other functional groups tend to vary with respect to coloration. Vanillin used for the detection of amines, amino acids, higher alcohols, phenols, and essential oils. The plate also visualized by UV light on wavelength $366 \mathrm{~nm}$. The results obtained from determination of the tests illustrated the presence of terpenoids, flavonoids and essential oils were present in both extracts. However, steroids, saponins and coumarins were absence in MGT but presence in MHI. On the other hand, the previous studies by Buenos et al. [24] were showed that the flavonoids were not found on methanol extract but only presence in the ethyl acetate and hexane extracts of propolis. These constituents may contribute to the MHI and MGT propolis therapeutic effect. Overall, from TLC analysis, the chemical composition and chemical fingerprint of propolis produced by H. itama are more complex compare to that of G. thoracica.

The differences in the phytochemical screening results of propolis might due to the time of harvest, storage, local flora extraction method [25] and the bee species. Besides using TLC method, analytical techniques such as high performance liquid chromatography (HPLC) and gas chromatography (GC), usually coupled to mass spectrometry (MS) were used to obtain molecular weight, structural information and identification [26]. However, the developed TLC method is a straightforward and efficient way for screening propolis samples at preliminary stage and for quality purposes. It is applicable to qualitatively determine biologically active compounds like flavonoids and others constituents in propolis using the specific detection reagent. 
Table 2. Phytochemical tests of the methanol extract propolis produced by stingless bees, H. itama (MHI) and G. thoracica (MGT)

\begin{tabular}{llccl}
\hline Constituents & Color detected & MHI & MGT & Chemical / Spray reagent \\
\hline Terpenoids & Pink & + & + & Anisaldehyde \\
Flavonoids & Blue fluorescence & + & + & Anisaldehyde \\
Saponins & Dark bluish & + & - & Vanillin-sulphuric acid \\
Steroids & Bluish green & + & - & Anisaldehyde \\
Coumarins & Light blue & + & - & UV $365 \mathrm{~nm}$ \\
Essential oils & Red and brown & + & + & Vanillin-sulphuric acid \\
All compounds & Yellow-brown & + & + & Iodine \\
\hline
\end{tabular}

Remarks: + ,detected; - , not detect

\section{DPPH Free Radical Scavenging Activity of MHI and MGT Propolis.}

The antioxidant test was conducted to determine the antioxidant potential of propolis extract, using the DPPH scavenging method. The use of DPPH to scavenge radicals has more advantages which easy to use, have high sensitivity and enabled to analyze of large numbers of samples in a short time. In order to measure antioxidant activity, the reduction of DPPH, a stable free-radical was used to evaluate the antioxidant activity of MHI and MGT propolis at concentrations varying from $6.25-800 \mu \mathrm{g} / \mathrm{mL}$ with quercetin as standards. The results show the variation of inhibition percentage. As shown in Figure 1, quercetin has the highest inhibition percentage (antiradical activity) closely followed by MHI while the MGT has the lowest and the differences is statistically significant.

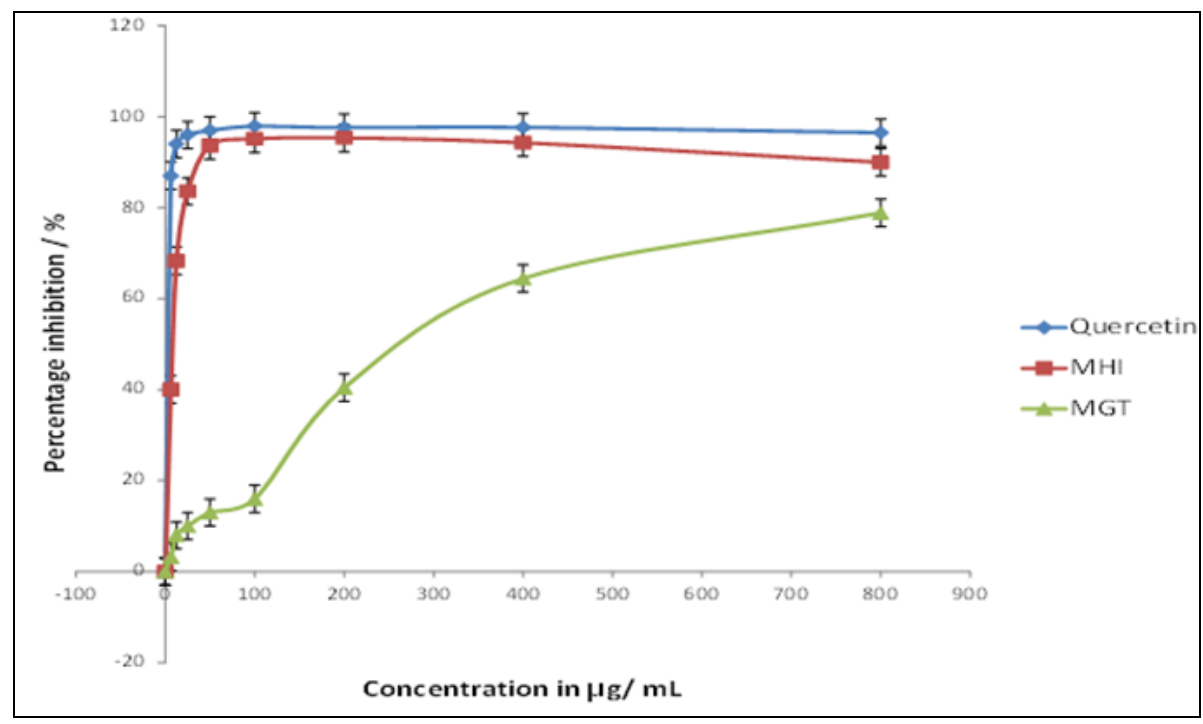

Figure 1. Plot of percentage inhibition against concentration of MHI, MGT and quercetin $(\mathrm{P}<0.05)$

The other parameters used for this test is $\mathrm{IC}_{50}$ and is defined as the concentration of extract required to capture the DPPH free radical by $50 \%$. Scavenging activity of MHI is comparable to that of quercetin with $\mathrm{IC}_{50}$ of $15 \mu \mathrm{g} / \mathrm{mL}$ and $10 \mu \mathrm{g} / \mathrm{mL}$, respectively (Figure 2). Meanwhile, MGT only moderately inhibited DPPH scavenging with IC50 of 
$270 \mu \mathrm{g} / \mathrm{mL}$ (Figure 2). A smaller $\mathrm{IC}_{50}$ value of the extract means the higher scavenging activity of the DPPH radical and, therefore, increased activity as an antioxidant. From the results above, propolis produced by MHI shows the higher antioxidant property compared to MGT. The difference in the antioxidant activity might due to the flavonoid content of propolis extracts or other compounds, which are potential antioxidants. As the previous studies by Fuliang et al. [28], the methanol extracts of Peruvian and Netherlands propolis exhibited stronger DPPH free radical scavenging activity than the corresponding water extract. It is due to its phenolic and flavonoid content, which is related to the antioxidant potential. The reasons behind the markedly higher radical scavenging activity exhibited by different types of propolis are probably due to their resin plant origin, climate, and resin collection time by the bees.

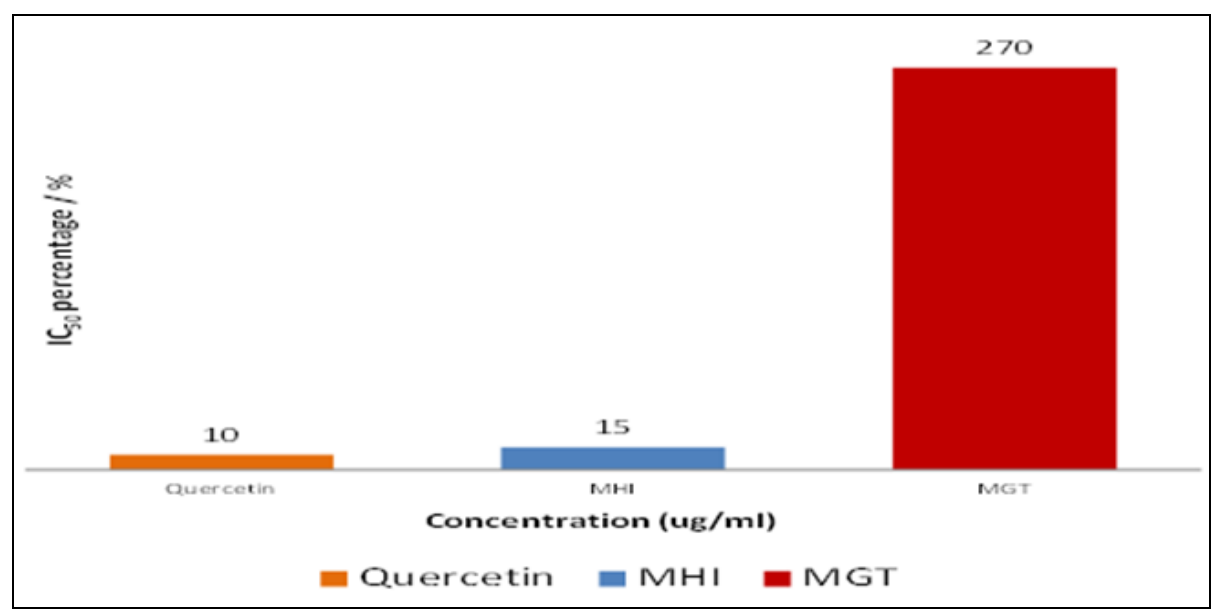

Figure 2. $\mathrm{IC}_{50}$ of MHI, MGT and Quercetin by DPPH scavenging method.

\section{Nitric Oxide activity}

Nitric oxide is a method to determined the potential of antioxidant that can react with superoxide to form the peroxynitrite anion, which can decompose to produce $\mathrm{OH}-$ and NO-. It has also been involved in a variety of biological functions, including neutrotransmission, vescular homeostasis, antimicrobial and antitumor activities. It was based on the principle that sodium nitro-prusside in aqueus solution at physiological $\mathrm{pH}$ spontaneously generates nitric oxide which interacts with oxygen to produce nitrite ions that can be estimated using Griess reagent. Scavengers of nitric oxide compete with oxygen leading to reduced production of nitrite ions. Large amounts of NO- may lead to tissue damage [27].

Nitric oxide scavenging activity was performed with MHI and MGT propolis and ascorbic acid as standard compound. The inhibition potential of all samples and standard preparations exhibited dose dependent manner. As shown in Figure 3, ascorbic acid was found more significantly active than both extracts. There is no significant difference between MHI and MGT propolis in the nitric oxide activity. From the graph, it was observed that as concentration increases, the percentage of inhibition scavenging is increasing linearly but constant at $150 \mu \mathrm{g} / \mathrm{mL}$ for all extracts and ascorbic acid (standard preparation). The $\mathrm{IC}_{50}$ for ascorbic acid was $30 \mu \mathrm{g} / \mathrm{mL}$, but there were no scavenging activity at $50 \%$ for MHI and MGT extracts propolis. Previous studies by Myint et al. [27] were found that labdane-type diterpenes, flavonoids and some phenolic compounds possessed potent nitric oxide inhibition activity in water and methanol extracts of Brazilian propolis. That may not be the case for propolis produced by $H$. itama and G. thoracica. 


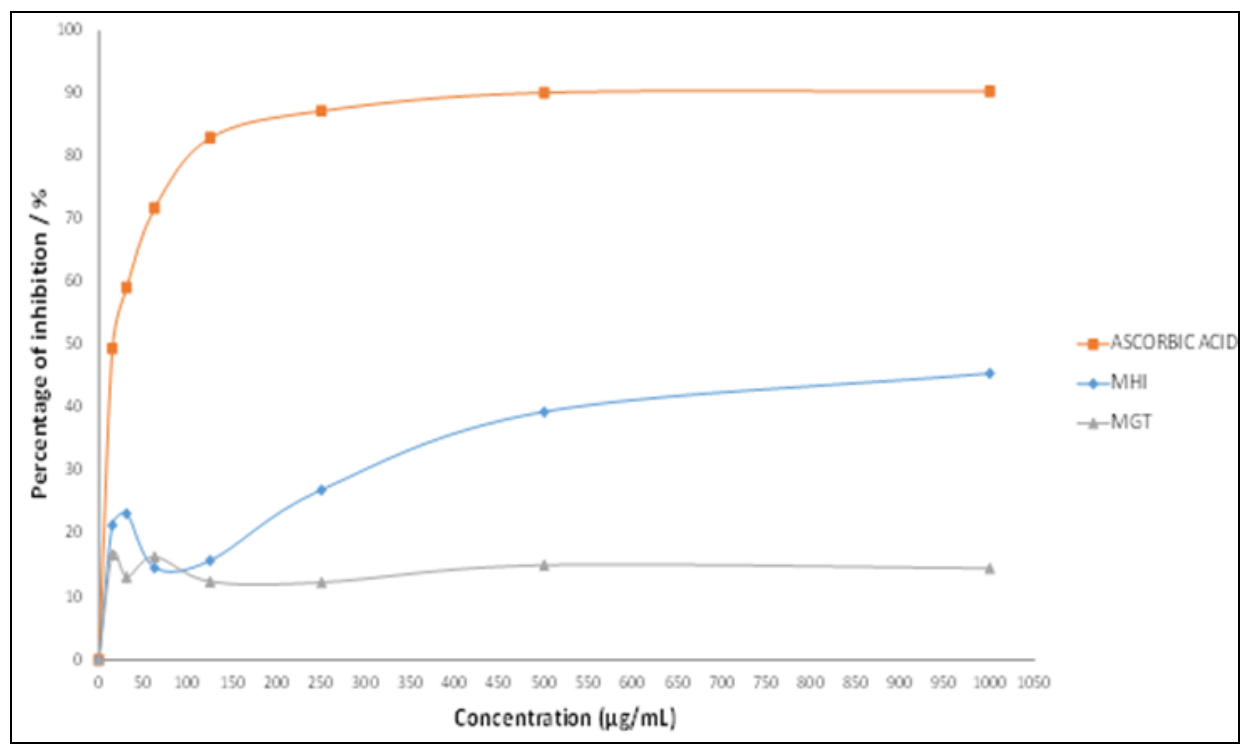

Figure 3. Plot of percentage inhibition against concentration of MHI, MGT and Ascorbic acid (P>0.05)

\section{Antidiabetic activity}

In this study, the hypoglycemic potential of both extracts (MHI and MGT) were evaluated by the $\alpha$-glucosidase inhibition assay. Acarbose was used as positive control. Results were tabulated in Figure 4 and 5 respectively. The $\mathrm{IC}_{50}$ was calculated for both extracts and were found significant $(\mathrm{P}<0.05)$ than acarbose. These differences in the concentration of propolis extracts may cause the differences in antidiabetic activities between MHI and MGT propolis. The $\mathrm{IC}_{50}$ of MHI and MGT were $2.5 \mu \mathrm{g} / \mathrm{mL}$ and $30 \mu \mathrm{g} / \mathrm{mL}$ respectively which were found lower than $\mathrm{IC}_{50}$ of acarbose $(190 \mu \mathrm{g} / \mathrm{mL})$. From results, it confirmed that the MHI showed potent antidiabetic potential than MGT and was higher than acarbose (positive control).

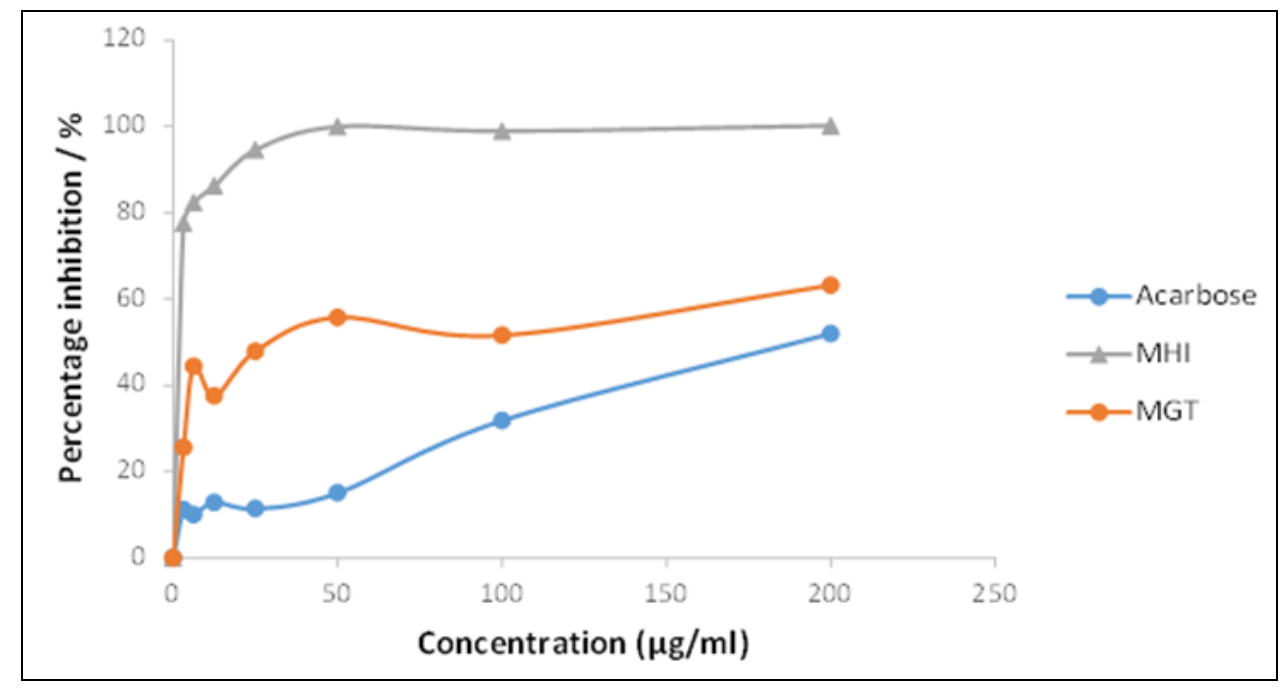

Figure 4. Plot of percentage inhibition against concentration of MHI, MGT and Acarbose $(\mathrm{P}<0.05)$ 


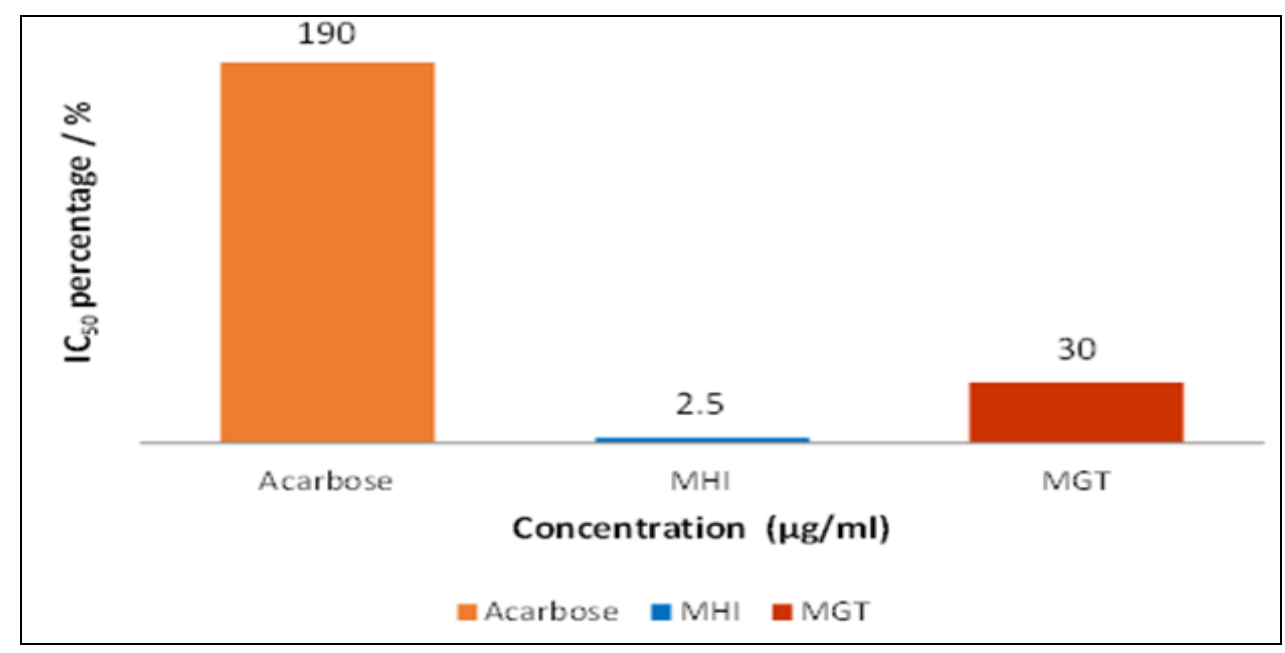

Figure 5. $\mathrm{IC}_{50}$ of MHI, MGT and Acarbose by antidiabetic activity

As the previous studies, flavonoids in propolis have an antioxidants activity and are thought to be the compound that is able to lower serum glucose levels through the inhibition of oxidative stress. In addition, the antioxidants activity of propolis can improve insulin receptor signaling in insulin resistant conditions, therefore the insulin sensitivity can be increased [28]. Similarly, result of MHI propolis have higher potential in antioxidant and also antidiabetic activity compare to that of MGT. However, previous reports have demonstrated that a propolis ethanol extract from Brazilian propolis improves insulin sensitivity during the prediabetic and diabetic stages on obese rats [29]. Thus, the chemical composition of propolis was strongly influenced by the source materials, species of bees and also types of the extraction.

\section{Conclusion}

From this study, it shows that bee species play role in determining the chemical and biological profile of particular propolis and should put into account in decision of further development for propolis. The data of physicochemical, preliminary phytochemical tests, biological activity and TLC profiling generated in this study will be the basis for authentication, standardization profile and quality control assessment of Malaysian propolis, especially produced by stingless bees, Heterotrigona itama and Geniotrigona thoracia. Further investigation on identification of marker compounds should be carried out to be use in propolis standardization.

\section{Acknowledgement}

This research work was supported by Research Acculturation Collaborative Report (RACE) grant scheme (Code: RR109), under the project Chemical Profiling and Chemometric Analysis of Malaysia Propolis by Ministry of Education Malaysia.

\section{References}

1. Souza, R. M., Souza De, M. C., Patitucci, M. L. and Silva, J. F. (2007). Evaluation of antioxidant and antimicrobial activities and characterization of bioactive components of two Brazilian propolis samples using a pKa-guided fraction-ation. Z Naturforsch, 62: 801 - 807.

2. Ledon, N., Casaco, A., Gonzalez, R., Merino, N., Gonzalez, A. and Tolon, Z. (1997). Antipsoriatic, antiinflammatory, and analgesic effects of an extract of red propolis. Acta Pharmacologica Sinica, 18(3): 274 -276.

3. Barros, M. P., Lemos. M., Maistro, E. L., Leite, M. F., Sousa, J. P., Bastos, J. K. and Andrade, S. F. (2008). Evaluation of antiulcer activity of the main phenolic acids found in Brazilian Green Propolis. Journal of Ethnoparmacology, 120: 372 - 377. 
4. Teixeira, É. W., Message, D., Negri, G., Salatino, A. and Stringheta, P. C. (2010). Seasonal variation, chemical composition and antioxidant activity of Brazilian propolis samples. Evidence-Based Complementary and Alternative Medicine, 7(3): 307 - 315.

5. Basnet, P., Matsushige, K., Hase, K., Kadota, S. and Namba, T. (1996). Four di-O-caffeoyl quinic acid derivatives from propolis. Potent hepatoprotective activity in experimental liver injury models. Biological and Pharmaceutical Bulletin, 19:1479 - 1484.

6. Suzuki, I., Hayashi, I., Takaki, T., Groveman, D. S. and Fujimiya, Y. (2002). Anti-tumor and anticytopenic effects of aqueous extracts of propolis in combination with chemotherapeutic agents. Cancer Biotherapy and Radiopharmaceuticals, 17: 553-560.

7. Duangphakdee, O., Koeniger, N., Deowanish, S., Hepburn, H. R. and Wongsiri, S. (2009). Ant repellent resins of honeybees and stingless bees. Insectes sociaux, 56: 333 - 339.

8. Righi, A. A., Negri, G. and Salatino, A. (2013). Comparative chemistry of propolis from eigght Brazilian localities. Evidence-Based Complementary and Alternative Medicine 2013: 1 - $15 .$.

9. Popova, M., Bankova, V., Bogdanov, S., Tsvetkova, I., Naydenski, C., Marcazzan, G. L. and Sabatini, A. G. (2007). Chemical characteristics of poplar type propolis of different geographic origin. Apidologie, 38: 306 311.

10. Sforcin, J. M. and Bankova, V. (2011). Propolis: Is there a potential for the development of drugs? Journal of Ethnopharmacology, 133: 253 - 260.

11. Simone-Finstrom, M. and Spivak, M. (2010). Propolis and bee health: the natural history and significance of resin use by honey bees. Apidologie, 41: 295 - 311 .

12. Marcucci, M. C. (1995). Propolis: chemical composition, biological properties and the therapeutic activity. Apidologie, 26: 83 - 99.

13. Markham, K. R., Mitchell, K. A., Wilins, A. L., Daldy, J. A. and Lu, Y. (1996). HPLC and GC-MS identification of the major organic constituents in New Zealand propolis. Phytochemistry, 42: 205 - 211.

14. Bankova, V., Castro De, S. \& Marcucci, M. (2000). Recent advances in chemistry and plant origin. Apidologie, $31: 3-15$.

15. Chen, Y. W., Wu, S. W., Ho, K. K, Lin, S. B., Huang, C. Y. and Chen, C. N. (1998). Characterization of Taiwanese propolis collected from different locations and seasons. Journal Science and Food Agriculture, 88: $412-419$.

16. Popova, M., Chen, C. N., Chen, P. Y., Huang, C. Y. \& Bankova, V. (2010). A validated spectrophotometric method for quantification of prenylated flavonones in Pacific propolis from Taiwan. Phytochemical Analysis, 21: $186-191$.

17. The Siddha Formulary of India.(1992). Part-I. Department of ISM \& H, Ministry of Health \& Family Welfare. Government of India. New Delhi.

18. World Health Organisation (1998). Quality Control Methods of Medicinal Plant Materials.Geneva.

19. Trease, G. E. and Evans, W. C. (1983). Textbook of Pharmacognosy. 12th edn. Balliese Tindall and Company Publisher, London. pp. 343 - 383.

20. Brand-Williams, W., Cuvelier, M. E. and Berset, C. (1995). Use of free radical method to evaluate antioxidant activity. LWT-Food science and Technology 28: 25 - 30.

21. Ho, S. C., Tang, Y. L., Lin, S. M. and Liew, Y. F. (2010). Evaluation of peroxynitrite scavenging capacities of several commonly used fresh spices. Food Chemistry, 119: 1102 - 1107.

22. Sancheti, S., Sancheti, S. and Seo, S. Y. (2010). Evaluation of antiglycosidase and anticholinesterase activities of Boehmeria nivea. Pakistan Journal of Pharmaceutical Sciences, 23: 236 - 240.

23. Emmanuel, T., Alfred, N. T., Pierre, B., Paul, S., Forche, P. A., Joseph, T. M., Nestor, F. F. T. and Robert, N. (2014). Phytochemical screening, antioxidant activity, total polyhenols and flavonoids content of different extracts of propolis from Tekel (Ngaoundal, Adamawa region, Cameroon). Journal of Phytopharmacology, 3(5): 321 - 329.

24. Buenos, M. I., Cunha, I. B. S., Marcucci, M. C. and Marassi, M. (1997). Evidence of lead contamination in propolis by X-Ray fluroscence analysis. In the International Apicultural Congress of Apimondia. The Centenary Congress Apimondia Publishing House, Bucharest, Romania.

25. Bankova, V. (2005). Chemical diversity of propolis and the problem of standardization. Journal of Ethnopharmacology, 100: 114-117. 
26. Pandey, M. K., Singh, G. N., Sharma Rajeev Kr and Sneh Lata. (2012). Standardization of Yakrit Plihantak Churna: An Ayurvedic Poly herbal formulation. International Journal of Pharmaceutical Sciences and Research, 3 (1): 171 - 176.

27. Myint, M. T., Aljun, H. B., Yasuhiro, T. and Kiyoshi, M. (2003). Inhibitors of nitric oxide (NO) production in murine macrophage-like J774.I cells from Brazillian propolis. Journal Tradional Medicine, 20: 22 - 29.

28. Fuliang, H. U., Hepburn, H. R., Xuan, H., Chen, M., Daya, S. and Radloff, S. E. (2005). Effects of propolis on blood glucose, blood lipid and free radicals in Rats with diabetes mellitus. Pharmacology Research, 51:147 52 .

29. Tasleem, A., Bhawana, S., Anjum, G., Vijay, K. and Rajesh, D. (2014). Anti-diabetic agents from medicinal plants: A review. Chemistry Biology Letters, 1(1): 1 - 13. 